\title{
Administrasi Islam Memandang Kebijakan Negara Dalam Melindungi Hak Milik Pribadi Dan Umum
}

\author{
${ }^{1}$ Cipta Lukmanul Hakim, ${ }^{2}$ Aip Zaenal Muttaqin \\ ${ }^{1}$ Sekolah Tinggi Ilmu Ekonomi dan Bisnis Syariah Nahdlatul Ulama, Indonesia; \\ ciptalukmanulhakim@gmail.com \\ ${ }^{2}$ Sekolah Tinggi Agama Islam Persis Garut, Indonesia; aipzaenal81@gmail.com
}

\begin{abstract}
The purpose of this study is to determine the state's protection of ownership both individual ownership and general ownership. The method used in this research is to use literature studies. After conducting a review of various information found that in Islam economic arrangements are regulated in the Qur'an and the Sunnah of the Prophet Muhammad. Then the Islamic economy does not run alone as understanding or other conventional economic concepts. the focus of Islamic economic studies or Islamic economics one of which is regarding the ownership of property. In Islam ownership is very flexible unlike capitalism which emphasizes freedom or socialism which forbids individual ownership. In the level of individual ownership, Islam really values and even protects it. More than that ownership in Islam can be more beneficial for others so that ownership does not depend on just one person. Instruments in the ownership of individual Islam accommodate through various things such as: the management of orphans' property, the distribution of inheritance, the obligation to pay zakat.
\end{abstract}

Keywords: Islamic Administration, Government, Civil Right, Zakat.

\section{Pendahuluan}

Ajaran islam tidak hanya bersifat praktik ritual keagamaan saja, tetapi menyangkut pada keseluruhan aspek kegiatan termasuk dalam kehidupan berbangsa dan bernegara. Islam adalah agama yang penuh dengan kemaslahatan bagi manusia. Maka dalam islam tidak mengenal kepada pemisahan antara agama dan negara atau sering orang menyebutnya dengan istilah sekularisme atau pemisahan antara agama dengan aspek aspek politik, negara, sosial ekonomi dan lain sebagainya.

Secara filosofis bahwa nilai-nilai Islam harus mampu masuk dan berjalan beriringan dengan pokok-pokok konsep nilai administrasi. Konsep Administrasi Islam ini memiliki maksud yaitu untuk memadukan nilai-nilai dan ajaran agama Islam yang terkandung dalam AlQuran dan Hadits kedalam kegiatan administrasi. Dalam kegiatannya, Administrasi Islam hadir sebagai pemberi petunjuk atau menaungi dengan nilai-nilai pokok ajaran Islam. Begitupun dalam bernegara, nilai-nilai ajaran Islam berperan sebagai penggabungan antara keduanya yakni agama dan negara kedalam kehidupan berbangsa dan bernegara.

Dalam bernegara, nilai-nilai ajaran Islam harus diwujudkan dalam seluruh proses berbangsa dan bernegara, mulai dari pengambilan kebijakan maupun dalam aktivitas lainnya. Dalam hal kebijakan negara, administrasi berperan sebagai proses dalam mengelola dan mengendalikan setiap kegiatan negara agar dapat berjalan sesuai dengan semestinya. Kemudian juga dimaksudkan agar negara harus berada sebagai penengah atau bersifat netral tidak memihak kepada siapapun. Negara harus mampu mengakomodir seluruh kepentingan 
setiap elemen bangsa, tidak seperti pada sistem kapitalis yang hanya mementingkan pada kaum pemodal saja atau seperti sistem sosialis yang hanya mementingkan kaum buruh saja.

Eulau \& Prewit (dalam Jones, 1984) memberikan pengertian bahwa kebijakan publik adalah keputusan tetap yang dicirikan oleh konsistensi dan pengulangan (repetitiveness) tingkah laku dari mereka yang mematuhi keputusan tersebut. Dalam kaitan tersebut, konsep ini seringkali diberikan makna sebagai tindakan politik, sejalan dengan pandangan Friedrich (dalam Wahab, 1997) bahwa kebijakan itu merupakan suatu tindakan yang mengarah pada tujuan yang diusulkan oleh seseorang, kelompok atau pemerintah dalam lingkungan tertentu sehubungan dengan adanya hambatan-hambatan tertentu seraya mencari peluang untuk mencapai tujuan atau mewujudkan sasaran yang diinginkan.

Pencapaian tujuan kebijakan memerlukan adanya pemahaman yang arif terhadap konteks lingkungan khusus (specific environmental context) atau kapabilitas lingkungan ecological capacity) dimana kebijakan itu diperhatikan. Hogwood dan Gunn (dalam Wahab, 1997) berpendapat bahwa untuk dapat mengimplementasikan kebijakan publik secara sempurna, maka diperlukan beberapa syarat tertentu, yaitu kondisi eksternal yang dihadapi oleh badan atau instansi pelaksana tidak akan menimbulkan gangguan atau kendala yang serius; untuk pelaksanaan program tersedia waktu dan sumber yang cukup memadai; perpaduan sumber yang diperlukan benar-benar tersedia; kebijakan yang akan diimplementasikan didasari oleh suatu hubungan kausalitas yang andal; hubungan kausalitas bersifat langsung dan hanya sedikit mata rantai penghubungnya; hubungan saling ketergantungan harus kecil; pemahaman mendalam dan kesepakatan terhadap tujuan; tugas dirinci dan ditempatkan dalam urutan yang tepat; komunikasi dan koordinasi yang sempurna; pihak yang memiliki wewenang kekuasaan dapat menuntut dan mendapatkan kepatuhan yang sempurna.

Smith (1973) mengemukakan bahwa kebijakan pemerintah telah didefinisikan sebagai tindakan yang memiliki maksud tertentu oleh pemerintah untuk menetapkan pola atau lembaga transaksi baru atau untuk mengubah pola yang telah mapan dalam lembaga. Kebijakan yang dirumuskan oleh pemerintah, kemudian, berfungsi sebagai kekuatan penghasil ketegangan di masyarakat. Sementara kebijakan diterapkan, ketegangan, ketegangan dan konflik dialami oleh mereka yang menerapkan kebijakan dan oleh kebijakan tersebut. Dari pendapat tersebut dapat ditarik suatu pemahaman bahwa kebijakan pemerintah telah didefinisikan sebagai suatu tindakan yang disengaja oleh pemerintah untuk menetapkan pola-pola transaksi maupun tindakan, ataupun kelembagaan ataupun mengubah pola-pola yang telah terbentuk lama di dalam lembaga. Kebijakan yang telah dirumuskan oleh pemerintah kemudian berfungsi sebagai kekuatan serta menghasilkan ketegangan dalam masyarakat yang dalam hal ini tentunya terdapat kekuatan yang pro maupun kontra. Saat kebijakan diimplementasikan adanya tention (ketegangan), strain, (ketegangan mental) dan konflik yang dialami oleh orang-orang yang melaksanakan kebijakan (implementor) dan oleh mereka yang dipengaruhi oleh kebijakan maupun mereka yang menjadi target kebijakan.

Sementara itu, konsep dasar kepemilikan adalah penguasaan seseorang terhadap barang atau harta dan barang tersebut dalam genggamannya baik secara nyata maupun secara hukum (Munawwir 1977). Kemudian Abd As-Salam memberikan pengertian bahwa kepemilikan adalah kepemilikan sebagai eksklusivitas syariat atas sebuah benda yang dimiliki oleh pemilik dengan wewenang hukum atas penggunaan dan penikmatannya serta pemusnahannya kecuali jika dilarang secara hukum (Suntana 2010). Secara garis besar bahwa kepemilikan adalah sesuatu yang berhubungan dengan harta benda. Menurut Wahbah Al-Juhaili bahwa pengertian harta adalah sesuatu yang dibutuhkan dan diperoleh manusia, baik berupa benda yang tampak seperti emas, perak, binatang, tumbuh-tumbuhan, maupun (yang tidak tampak), yakni manfaat. An-Nabhani (2002), menguraikan bahwa kepemilikan dapat dibedakan menjadi tiga bagian 
besar yaitu, kepemilikan Inividu, kepemilikan umum, kepemilikan negara. Pembagian ini merupakan turunan ataupun efek dari nilai filsafat bahwa kepemilikan senantiasa tidaklah baku.

Catatan sejarah pada zaman dahulu yaitu pada zaman Nabi Muhammad SAW, bagaimana pada waktu itu Nabi membuat salah satu lembaga yang disebut dengan hisbah. Dimana hisbah ini merupakan lembaga negara yang bertugas mengawasi dan mengendalikan kegiatan masyarakat dalam konteks perekonomian. Sehingga pada saat itu kegiatan ekonomi dijamin dengan tidak adanya perlakuan tidak sesuai terhadap konsumen maupun penjaminan keamanan dan kesehatan beraktivitas (Saefudin 2011). Berbagai kebijakan ekonomi yang secara aturan dimuat dalam berbagai kerangka regulasi yang mengaturnya, maka penjaminan terhadap hak milik baik yang sifatnya pribadi maupun umum harus diakomodir dalam peraturan-peraturan tersebut. Seperti halnya dalam menciptakan rasa adil, adanya pemerataan ekonomi, pemerataan pendapatan, membuat kesesuaian aturan kegiatan ekonomi. Maka dengan demikian, atas uraian pendahuluan tersebut penulis tertarik untuk menulis artikel ini dengan tujuan yaitu untuk mengalisis bagaimana administrasi islam memandang kebijakan negara dalam melindungi hak milik pribadi dan umum.

\section{Metode Penelitian}

Penelitian ini menggunakan pendekatan kualitatif dengan jenis penelitian studi kepustakaan. Implikasi dari menggunakan pendekatan ini terlihat dari alur berpikir penelitian yang induktif, yaitu dari umum ke khusus. Selain itu, penelitian ini tidak membahas hubungan sebab-akibat, melainkan ingin lebih mendalami dan menelusuri suatu topik atau isu tertentu dikaitkan dengan konsep dan teori yang dalam hal ini adalah tentang bagaimana administrasi islam memandang kebijakan negara dalam melindungi hak milik pribadi dan umum. Jenis data dan informasi yang dipilih yaitu data sekunder sehingga peneliti tidak perlu untuk melakukan penelitian lapangan. Dalam rangka mengumpulkan data dan informasi, penelitian ini menghimpun berbagai pendapat dari ahli dan pakar dalam sejumlah literatur buku maupun dari kitab-kitab dengan kajian yang sesuai. Kemudian penulis melakukan analisis terhadap pendapat-pendapat tersebut dan memberi tanggapan dan analisis.

\section{Hasil dan Pembahasan}

\section{Analisis Teori Hak Milik}

Pertama, kepemilikan individu, ialah harta benda yang kepemilikannya dimiliki oleh seseorang ataupun oleh individu. Menurut Al Mishri (2006) ada beberapa ciri ataupun prasyarat untuk kepemilikan perorangan ataupun pribadi.

1. Harta yang dimiliki harus senantiasa bermanfaat, artinya harta yang yang dimiliki tidak menjadi suatu kejelekan ataupun kemadharatan bagi kehidupan diantara sesama masyarakat.

2. Pemahaman diantara semua masyarakat bahwa tidak setiap harta benda bisa dimiliki oleh perorangan ataupun individu.

3. Kepemilikan harta benda tidak selamanya menjadi kepemilikan kita. Akan tetapi, ada bagian ataupun kepemilikan orang lain atas harta benda perorangan ataupun individu.

4. Perolehan ataupun cara pendapatan harta benda harus dari jalan yang baik ataupun halal. 
Dalam memperoleh kekayaaan atau hak milik pribadi Islam pun telah mengaturnya, tapi bukan dalam aturan untuk pembatasan mencari harta kekayaan. Akan tetapi, penekannanya lebih kepada cara memperolehnya yaitu memperolehnya harus dengan jalan yang baik atau halal serta akhir dari pada penggunaan harta benda tersebut.

Kedua, Kepemilikan umum dimana kepemilikan ini adalah yang kepemilikannya bisa dimanfaatkan untuk kepentingan bersama. Karena pada dasarnya tidak semua benda atau barang tidak dapat kita kuasai secara pribadi karena dikhawatirkan akan terjadi praktik-praktik pengusaaan secara perseorangan ataupun monopoli. Diantara benda-benda yang dapat dimanfaatkan oleh bersama antara lain adalah air, api, udara, sumber energi dan lain sebagainya. Oleh karena itu maka, penguasaan terhadap benda-benda tersebut sebaiknya di dilimpahkan pada pihak yang dirasa mempunyai kewenangan untuk mengelolanya yaitu negara ataupun pihak lain yang disyaratkan mempunyai kemampuan untuk pengelolaannya yang sesuai dengan kaidah ataupun norma (Nawawi 2009). Sebagaimana yang dinukilkan dalam sabda nabi Muhammad SAW yang diriwayatkan oleh Imam Abu Dawud yaitu dalam tiga hal, yakni air, api dan rerumputan. Dengan makna dari hadits tersebut adalah sebaiknya penguasaan terhadap benda-benda yang sangat penting untuk kebutuhan hidup orang banyak sebaiknya di wewenangkan kepada pemerintah. suatu negara.

Dalam Negara Kesatuan Republik Indonesia sendiri, untuk benda-benda yang menyangkut hidup orang banyak diatur dalam aturan konstitusi negara yang termuat dalam Undang Undang Dasar 1945. Dengan bunyi sebagai berikut cabang-cabang produksi penting bagi negara dan menguasai hajat hidup orang banyak dikuasai oleh negara. Dengan pemahaman seperti yang ditanggapi oleh Jimly Asshidiqie bahwa dipahami dalam makna dikuasai dalam pengertiannya yang luas, yaitu termasuk juga dimiliki oleh negara dan orang atau subjek asing tidak boleh menjadi pemilik hak atas tanah. Ketiga, Kepemilikan Negara yaitu seluruh kegiatan baik pengelolaan maupun penggunannya harta benda di lakukan oleh negara melalui kewenangan kepala negara atau pemimpin. Pemimpin memilik kewengan untuk menggunakannya yang dimana hasil dari pengelolaannya itu digunakan kembali untuk keperluan masyarakat luas dan juga untuk membiayai keperluan tugas pemimpin tersebut.

\section{Peran Negara Menurut Konsep Administrasi Islam}

Makna dari keadilan sosial merupakan suatu hal yang sangat penting dalam perekonomian, karena itu mencerminkan bahwa berjalannya perekonomian dengan baik. Dengan kata lain bahwa adanya peran negara hadir sebagai upaya untuk mewujudkan kesejateraan masyarakat ataupun kesejahteraan ekonomi. Peran negara hadir untuk menyebarkan perekonomian yang bukan hanya milik individu akan tetapi dimiliki atau dinikmati oleh semua masyarakat.

Terdapat dua aspek yang bisa dilakukan oleh Pemerintah dalam rangka pengaturan ekonomi, antara lain yaitu:

1. Mengkonstruksi aturan-aturan atau regulasi yang bersumber dari nash Syar'i maupun Qath'i. Supaya untuk menjamin kegiatan ekonomi masyarakat berjalan dengan baik tanpa melakukan kegiatan-kegiatan ekonomi yang dilarang. Seperti, menimbum barang, kegiatan yang ribawi, jual beli yang salah dan lain sebagainya.

2. Selalu Melakukan diskusi dan dialog ataupun bahasa agamanya ijtihad oleh orang-orang yang mampu di bidangnya atau kredibel sehingga produk hukum terisi dengan konsepsi ekonomi dalam naungan hukum Islam (Hudda 2011). 
Perlindungan terhadap hak milik baik pribadi maupun hak milik umum diejawantahkan melalui peraturan ataupun kerangka hukum perundang-undangan sebagai salah satu peran negara dalam mengeluarkan kebijakan. Dengan adanya peraturan peraturan tersebut akan berdampak terhadap kehidupan masyarakat, misalnya dalam segi perlindungan terhadap harta benda milik masyarakat ataupun kesejahteraan masyarakat lainnya. Sebagai gambaran terdapat beberapa contoh mengenai pola pemerintahan zaman kekhalifahan yang dimana pada waktu itu peran negara sangat muncul dalam melindungi masyarakatnya yaitu dengan dikeluarkannya kebijkan pemerintah atau negara terhadap perlindungan hak milik masyarakat oleh negara maupun oleh pihak yang lainnya.

Berikut beberapa contoh catatan sejarah pada zaman kekhalifahan bagaimana membuat sebuah kebijakan dalam rangka perlindungan terhadap warga masyarakatnya. Yaitu, perlindungan terhadap hak-hak para petani antara lain:

1) Tersedianya bantuan yang diberikan oleh pemerintah melalui lemabaga keuangan pemerintah terhadap para petani yang gagal terhadap pengelolaan pertaniannya.

2) Adanya berbagai jaminan baik jaminan sakit, masa tua, ataupun ketidak mampuan mengelola pertanian.

3) Pemerintah dalam hal ini khalifah selalu memperhatikan terhadap hasil pertanian, dan memberikan konvensasi apabila hasil dari pertanian itu mengalami kerusakan dengan sumber keuangan dari badan keuangan negara.

4) Ketika terjadi relokasi lahan yang tidak dapat diindahkan untuk keperluan negara maka negara mengganti dengan sesuai ataupun melakukan pemindahan ke tempat lain dengan fasilitas-fasilitas yang cukup memadai (Rahman 1995).

\section{Perlindungan Terhadap Hak Milik Pribadi dan Umum}

Suatu barang yang kepemilikannya oleh pribadi pada prinsipnya hanya kepemilikan yang sementara taupun kepemilikan yang tidak absolut atau kepemilikannya mutlak, artinya setiap kepemilikan suatu barang atau kekayaan disana terdapat hak milik orang lain dengan kata lain ada pembatasan kepemilikan karena kekayaan atau harta tersebut untuk hajat hidup orang banyak. Oleh karenanya maka, peran pemerintah dibutuhkan untuk ikut campur atau intervensi dalam rangka pengamanan barang-barang tersebut.

Al-Mishri memberikan suatu pemahaman mengenai makna intervensi pemerintah, beliau memberikan gambaran dengan membagi makna intervensi kedalam beberapa klasifikasi diantaranya adalah: hukum mawaris atau pembagian harta warisan, harta anak yatim, kewajiban zakat dan mencegah kemadhorotan (Al-Mishri 2006). Sedangkan Baqir Shadr mengemukakan bahwa pemerintah harus ikut campur tangan dalam kegiatan perekonomian sebagai upaya untuk mengamankan atau menjamin penyesuaian hukum-hukum islam yang berkaitan dengan kegiatan ekonomi (Suntana 2010).

1. Hukum Mawaris (Pembagian Warisan)

Harta peninggalan orang yang sudah meninggal sebaiknya dibagikan kepada para ahli warisnya atau yang disebut dengan zawil furud. Pembagian harta tersebut merupakan suatu keharusan dalam syariat islam. Maka oleh karena itu harus adanya regulasi yang jelas untuk mengaturnya, karena sifatnya yang sangat rentan akan pertikaian apabila dibagikan dengan tidak sesuai atau tidak adil. Sehingga di dalam kajian ilmu fiqih, hukum mawaris merupakan bagian yang terkhususkan yang sering dibahas dalam kajian fiqih mawaris. 
Kemaslahatan atau kebaikan menjadi tujuan utama dalam pembagian harta waris ini, agar supaya jauh dari kemadharatan dan menghindari dari pertikaian dan perselisihan. Maka makna kemaslahatan disini yaitu utuk menjaga dan memelihara maksud syara' (Hidayat 2009). Para ulama ahli hadits memberikan pandangan menganai hadits tersebut, bahwa yang dimaksud dalam ashobah tersebut atau sisa harta warisan dibagikan kepada ahli waris laki-laki karena peran dan tanggungjawab laki-laki memberikan nafkah kepada keluarganya. Sedangkan perempuan diberikan nafkah oleh suaminya. Karena laki-laki merupakan penanggung jawab dalam rumah tangga dan sebagai pemimpin dalam rumah tangga dan anggota keluarganya, maka dari itu laki-laki harus mempunyai kekuatan keauangan yanga baik (Mardani 2011).

Maka dengan demikian, kiranya perlu ada aturan atau regulasi yang mengatur pembagian harta waris tersebut. Yaitu adanya sistem kerangka hukum yang mengatur terhadap pembagian warisan baik berupa perundang-undangan ataupun aturan dibawah undang-undang. Akan tetapi harus digaris bawahi juga peraturan-peraturan yang dibuat baik undang-undang ataupun aturan dibawah undang-undang harus dibuat berdasarkan atau berpedoman pada hukum waris menurut syariat Islam. Atau dengan kata lain formalisasi hukum islam agar supaya kedudukan hukum Islam tingkatannya lebih kuat dalam tata aturan perundang-undangan di Indonesia.

\section{Harta Anak Yatim}

Salah satu hal perlu adanya intervensi pemerintah atau negara adalah menjaga amanah harta anak yatim, sebagaimana para mufassir menjelaskan Q.S An-Nisa ayat 5 bahwa harta yang dimaknakan dalam ayat itu adalah harta anak yatim, akan tetapi secara hakikat bahwa harta itu pemberian dari Allah SWT kepada manusia untuk melakukan kehidupan. Sehingga berkenaan dengan itu maka harta tersebut harus dikelola oleh orang yang mampu menggunakannya. Sepanjang anak yatim tersebut belum mampu menggunakan hak atas harta tersebut. Adapun ketika belum mampu menggunakan serta mengelolanya maka harta tersebut dilarang diberikannya sampai pada waktu mampu untuk mengelolanya.

Al Mishri memberikan pendapat mengenai hal ini, pendapatnya mengatakan bahwa karena harta memiliki kedudukan yang sangat penting untuk kepentingan dalam hidup dan kehidupan maka harus ada sistem pengelolaan. Disini negara hadir sebagai pemangku kekuasaan dan juga pemangku kepentingan untuk melakukan andil ambil bagian dalam pengelolaannya sebagai pemberi kemaslahatan untuk semuanya. Amanah yang begitu besar dalam mengelola harta anak yatim ini menjadi suatu kebaikan dan kebajikan bagi yang benarbenar mengelolanya.

Peran pemerintah atau negara untuk ikut campur atau intervensi dalam pengelolaan harta anak yatim ini misalnya membentuk lembaga yang khusus menangani hal tersebut atau memberikan kewenangan pada lemabaga tertentu untuk memberikan penilaian ataupun pengujian kepada siapa harta ini akan diberikan sebagai pengelola. Kemudian pemerintah atau negara juga hadir untuk melakukan evaluasi atas pengelolaan harta yang diberikan kepada yang diamanahi tersebut.

\section{Kewajiban Zakat}

Dalam tinjauan aspek bermuamalah zakat sangat berguna sekali sebagai sarana penyebaran harta dan juga sebagai sarana peningkatan produktivitas. Penyebaran harta yang dimaksud adalah bagaimana zakat itu sendiri bisa digunakan sebagai sarana penyebaran harta dari yang berkecukupan kepada yang kurang mampu. sehingga dengan zakat ini akan menjadikan rasa kebersamaan terhadap sesama menjadi lebih terjaga. Kemudian, zakat sebagai sarana untuk peningkatan produktivitas yaitu cara pengelolaan zakat yang tadinya hanya bersifat pada pemenuhan makanan saja akan tetapi dirubah kepada pola pengelolaan 
pemberdayaan. Dengan kata lain bahwa zakat bukan hanya untuk kebutuhan yang sifatnya jangka pendek saja akan tetapi sebagai pemenuhan untuk jangka yang lebih panjang. Ketika zakat digunakan sebagai pemenuhan jangka pendek artinya zakat hanya digunakan untuk keperluan konsumsi saja. Namun, ketika zakat digunakan sebagai pemenuhan kebutuhan yang lebih panjang artinya zakat itu digunakan untuk pemberdayaan masyarakat. Misalnya dengan pemberian bantuan finansial yang bersumber dari dana zakat kemudian dikelolanya sehingga dapat menghasilkan keuntungan bagi pihak pengelolanya tersebut. Dengan aturan dan pola tersebut diharapkan nantinya pihak pengelola atau orang penerima dana zakat produktif ini akan berubah menjadi pemberi zakat.

Potensi zakat yang begitu besar dan juga memiliki efek yang sangat baik guna pembangunan ekonomi umat, maka sepatutnya pemerintah atau negara untuk turun tangan dalam pengelolaan dengan melakukan intervensi terhadap pengelolaan dana zakat ini. Turun tangan pemerintah atau negara dalam hal ini bukan dimaksudkan untuk mengambil keuntungan dari dana zakat tersebut, akan tetapi negara atau pemerintah menjamin akan pengelolaan dana zakat sehingga dapat tersalurkan kepada yang berhak untuk menerimanya. Selaian itu, turun tangan pemerintah atau negara terhadap pengelolaan zakat ini, bisa melakukan akselresai dalam pengumpulan dana zakat, karena dengan pengelolaan secara profesional dan modern sehingga para muzaki atau orang yang membayar zakat akan lebih tenang atau lebih nyaman. Kemudian juga di sisi lain pemerintah atau negara bisa menggunakan kekuasaanya untuk melakukan terobosan dengan diterbitkannya aturan atau regulasi mengenai zakat ini. Seperti misalnya kewajiban untuk membayar zakat diwajibkan namun apabila yang tidak ingin membayar zakat negara atau pemerintah dapat melakuka intervensi melalui aturan atau kebijakan yang dapat dibuatnya. Sebagaimana terjadi pada zaman ke Khalifahan Abu Bakar As Shiddiq.

\section{Mencegah Kemadharatan}

Intervensi atau campur tangan pemerintah (negara) disini yaitu, selain pada aspek-aspek yang telah disebutkan di atas, maka campur tangan pemerintah bisa dilakukan untuk meminimalisir terhadap kemadharatan dari akibat pertikaian sesama umat. Pemerintah harus menjadi penengah serta sebagai pengambil keputusan samapai pada penyelesaian masalah ketika terjadi perselisihan atau pertikaian yang terjadi diantara sesama warga masyarakat. Karena kemadharatan bisa timbul akibat dari kepemilikan harta benda pribadi atau perorangan. Kepemilikan pribadi pada prinsipnya tidak bermasalah dengan siapapun, akan tetapi akan bermasalah ketika barang asalnya pribadi itu dapat mengganggu orang lain yang sama ketika membutuhkan terhadap barang itu sendiri.

Dalam suatu riwayat yang di jelaskan oleh Abu Ja'far dari ayahnya Ali Zainal Abidin menjelaskan bahwa:

"Samrah memiliki sebuah pohon kurma, dimana dahannya menjulur pada tembok rumah salah seotrang Anshar, orang Anshar dan dan keluarganya merasa terganggu dengan dahan tersebut, kemudian dia mengadu kepada Rasulullah, Rasulullah kemudian bersabda kepada orang yang mempunyai pohon kurma: 'juallah pohon kurma itu'ternyata dia tidak mau menjualnya. Kemudian Rasulullah bersabda: 'potonglah pohon itu' diapun tidak mau memotongnya. Rasulullah bersabda: 'berikanlah pohon itu kepadanya, maka engkau akan mendapatkan gantinya di surga" dan dia masih tidak mau. Kemudian Rasulullah berpaling dan berkata kepada orang itu: 'engkau adalah sumber bencana' dan selanjutnya Rasulullah menghadap kepada orang Anshar dan bersabda: 'pergilah dan cabut pohon itu!'”. 
Penjelasan dari hadits tersebut dapat dimaknai bahwa pemerintah atau negara dituntut untuk bisa menyelesaikan permasalahan yang terjdi ketika ada perselisihan diantara warga masyarakatnya. Pemerintah dalam hal ini harus menjadi hakim ataupun pengambil keputusan yang dapat memuaskan kepada semuanya bahakan negara harus berposisi pada kebenaran. Pemerintah atau negara harus mampu mencegah kemadharatan dan mencegah warga masyarakatnya dari kemadharatan. Bukan pemerintah atau negara menikmati kemadhorotan yang ditimbulkan dari warga masyarakatnya, sebagaimana kaidah ushul fiqih menjelaskan bahwa menghidarkan kerusakan lebih diutamakan dan diprioritaskan dari pada mengambil kemaslahatan".

\section{Simpulan}

Secara garis besar bahawa kepemilikan dapat di kategorikan menjadi tiga kategori besar antara lain adalah kepemilikan individu, kepemilikan umum dan kepemilikan negara. Kepemilikan tersebut perlu dijaga dan diperhatikan, maka oleh karean itu, untuk menjaga kepemilikan tersebut harus adanya campur tangan pemerintah sebagai wujud untuk pemberian rasa aman terhadap kepemilikan tersebut. Campur tangan pemerintah atau negara disini bisa melalui penyedian aturan-aturan perundang-undangan. Dengan adanya regulasi atau aturan tersebut diharapkan bisa menjaga umat dari kepemilikannya baik harta maupun sampai pada kesejahteraannya. Sebagai upaya untuk melaksanakan keputusan keputusannya tersebut negara dalam hal ini dilakukan oleh pemerintah memerlukan suatu alat untuk melaksanakan kebijakannya itu sendiri antara laian adalah kewajiban untuk mengeluarkan zakat, pembagian harta warisan, mencegah kemadharatan dan juga harta anak yatim.

\section{Referensi}

Abdul, K.A., et al. (1999) Sistem, Prinsip dan Tujuan Ekonomi Islam. Bandung: Pustaka Setia. Al-Juhaili, W. (1989). Al-Fiqh Al-Islami wa Adillatuhu Juz IV. Damsyik: Dar Al-Fikr.

Al-Maliki. (2001). Politik Ekonomi Islam. Jatim: Al-Izzah.

Al-Mishri. (2006). Pilar-Pilar Ekonomi Islam. Yogyakarta: Pustaka Pelajar.

Ali, Z. (2008). Hukum Ekonomi Syariah. Jakarta: Sinar Grafika.

An-Nabhani, T. (2002). Membangun Sistem Ekonomi Alternatif Perspektif Islam, oleh Moh. Maghfur Wachid. Surabaya: Risalah Gusti.

Asshiddiqie, J. (2013). Komentar Atas Undang-Undang Dasar Negara Republik Indonesia Tahun 1945. Jakarta: Sinar Grafika.

Ash-Shidiqie, M.H. (2013). Falsafah Hukum Islam. Semarang: PT.Pustaka Rizki Putra.

Budi, A.H. (2009). Memahami Dasar dasar Ilmu Fara 'id. Bandung: Titian Ilmu.

Departemen Agama RI. (2009). Al-Qur'an dan Tafsirnya Jilid 1. Jakarta: Departemen Agama RI.

Djazuli, A. (2009). Fiqh Siyasah. Jakarta: Prenada Media Group.

Idri. (2015). Hadis Ekonomi: Ekonomi dalam Perspektif Hadis Nabi. Jakarta: Prenadamedia Group.

Karim, A. (2012). Sejarah Pemikiran Ekonomi Islam. Jakarta: PT RajaGrafindo Persada. 
Mardani. (2011). Ayat-Ayat Dan Hadis Ekonomi Syariah. Jakarta: RajaGrafindo Persada.

Munawwir. (1997). Kamus Al Munawwir. Surabaya: Pustaka Progresif.

Muti, A., Huda, N. (2011) Keuangan Publik Islam: Pendekatan Al-Khoroj. Bogor: Ghalia Indonesia.

Naf'an. (2013). Ekonomi Makro: Tinjauan Ekonomi Syariah. Yogyakarta: Graha Ilmu.

Nawawi, I. (2009). Ekonomi Islam: Perspektif Teori, Sistem, dan Aspek Hukum. Surabaya: CV. Putra Media Nusantara.

Praja, J.S. (2009). Filsafat Hukum Islam. Bandung: PT. Lathifah Press.

Qaradhawi, Yusuf. (2005). Spektrum Zakat Dalam Membangun Ekonomi Kerakyatan. Jakarta: Zikrul Hakim.

Qodri, A.A (2004). Membangun Fondasi Ekonomi Umat. Yogyakarta: Pustak Pelajar.

Rahman, A. (1995). Doktrin Ekonomi Islam Jilid 1. Yogyakarta: Dana Bhakti Wakaf.

Rianto M.N. (2010). Teori Makro Ekonomi Islam. Bandung:Alfabeta

Saefudin, A.M. (2011). Membumikan Ekonomi Islam. Jakarta:PT PPA Consultans.

Suhendi, H. (2014). Figh Muamalah. Jakarta: PT RajaGrafindo Persada.

Sukirno, S. (2011). Ekonomi Pembangunan. Jakarta: Kencana Prenada Media Group.

Suntana, I. (2010). Politik Ekonomi Islam. Bandung: CV Pustaka Setia.

Syafei, R. (2001). Fiqh Muamalah. Bandung: CV Pustaka Setia.

Tanjung, S., Izzan, A. (2007). Refernsi Ekonomi Syariah: Ayat ayat Al-Quran yang berdimensi Ekonomi. Bandung:PT.Ramaja Rosdakarya.

Umer, M.C. (2000) Islam dan Pembangunan Ekonomi. Jakarta:Gema Insani. 